\title{
MAKING AND UNMAKING TERRITORIES WITH PLANTS IN THE RIVERINE PEAT LANDSCAPE OF CENTRAL KALIMANTAN
}

\begin{abstract}
Central Kalimantan, located on the Indonesian side of Borneo, has often been described as a state frontier area where rapid changes take place in legal and administrative regimes and in the rules that govern access and ownership to land and nature. Today, frontier development includes state and non-state actors that bring natural resource projects aimed at producing long-term effects by engaging local people in the commodification of nature. Local people adopt and abandon these projects at a rapid pace due to changing conditions, policies, and natural hazards. I will explore commodification in terms of territorial projects and the spatial and temporal reordering of human-nature relations within the landscapes of Central Kalimantan. Linked to the territorial expansion of trees and plants, commodification challenges local environmental practices and forms of sociality. The paper argues that the commodification of nature and the territorial aspects of this bring new layers of complications and thus have unexpected effects on the lives of local populations.
\end{abstract}

Keywords: frontier, commodification, plants, landscape, state-making, Kalimantan

\section{INTRODUCTION}

In October 2019, the village of Sei Tobun was mostly covered with smoke in the mornings. ${ }^{1}$ Yellowish haze completely obscured the other side of the Kahayan River. I and the family I was living with were plagued by coughing and sometimes our eyes stung. By noon, we could breathe okay again. On the day of my arrival, I was walking upriver along the Kahayan River. On my way, I met three women who sat on the veranda of a wooden plank house near the water. A grandmother (about sixty years old) and her husband, a former head of the Saka
Dong River for many years, lived in the house with their middle-aged daughter and her family. I sat down with the women. Talking over each other, they told me about the fires that had been burning land and trees for the last months. 'My heart aches. I have not been able to go to the garden for one month now', the grandmother explained, as fire had destroyed 3,000 fouryear-old sengon trees. ${ }^{2}$ She did not have plans to replace the ones that had burned in the disaster (I. musibab) ${ }^{3}$. The women, as well as the majority of the other villagers, had planted sengon trees after the 2015 fires. During the dry season in 2019, some of the rivers crossing the 
peatland had become completely parched. The daughter told me how they saw that the sengon trees became 'dry' and apes ate their desiccated bark. It is different from rubber, because rubber trees don't burn so easily, she continued (Diary 10.10.2019). These rapidly growing sengon trees were part of the social forestry programme, introduced to the area for industrial purposes because of the establishment of a new plywood factory in the village in 2016.

In the degraded swamp forests of Central Kalimantan, forestry and wetland territorial projects commodify the local landscapes at an accelerated pace. These territorializing projects involve multiple state, non-state, human, and non-human agents, such as trees and plants, which have been less explored in the context of the making of territories (Besky and Padve 2016). However, recent research has importantly examined the role of plants not as resources but parties or companions that interact with humans, suggesting that plants and human and more-than-human engagements are crucial to forming landscape processes (Head et al. 2014: 863; Tsing 2012; 2015) and territories (Besky and Padwe 2016). This article focuses on the role of commodity plants in the production of (new) forms of territories in the village of Sei Tobun in Central Kalimantan, Indonesia. My questions are: 1) what is the role of plants in the making of territories within the socio-natural peat landscapes; and 2) what kinds of relational, material, and temporal qualities do commodity plants bring to human territorial strategies and practices.

The Cambridge Dictionary (n.d.) defines territory 'as (an area of) land, or sometimes sea, that is considered as belonging to or connected with a particular country or person'. This definition refers to the understanding of territory as a geographical area, space and object, following the political or geography sciences
(Elden 2010), where it used to be understood until recently as an object or space. Importantly, Deleuze and Guattari suggested that territory could be understood as an act (rather than object), stressing the eventual and processual nature of territory; territorial process comprises deterritorialization, reterritorialization, and territorialization (1987: 314; Brighenti 2010). In a recent article, Besky and Padwe (2016: 9) not only discuss territory as an effort to extend control and power over space and populations by both state and non-state actors, but how these processes entangle with plants. Thus, plants are not only indexes of power in landscapes, but they are actors that qualify the processes of interactions and relations when they reterritorialize and deterritorialize landscapes. I am not discussing plants and landscapes as having intentional agency, but rather, following Allerton's definition in relation to the scholarly and empirical discussion in the context of Southeast Asia, where agency refers to 'exerting power or producing an effect' allowing also for local worldviews according to which stones, mountains, trees, and so forth often have agency (2013:242-243). In this line of thought, territory refers to processes whereby social relations and spatial boundaries are formed, linking the concept with specific rhythms and temporalities, when 'the expressive qualities of territory combine among themselves to create certain themes' (Brighenti 2010: 64). Understanding territory as a process of marking that expresses access (or inaccessibility) and boundaries takes into account that plants and non-human actors are active parties in the production of territory and its qualities. Thus, it critically questions earlier scholarly discussions, which defined territory as a fixed material space and object.

The approach proposed by Besky and Padwe contributes to the recent scholarly discussion on 
the need to recentre anthropocentric studies in relation to ontological and multispecies dynamics and entanglements in different landscape contexts (Haraway 1991; Kohn 2014; Tsing 2012; 2015). For instance, new studies explore multispecies relations with a focus on commodity plants, sometimes with violent qualities. Along this line of thought, Sophie Chao has discussed how the Marind of West Papua experience oil palm as a commodity plant that causes spatial and temporal disorientation and a haunted feeling of being eaten by this 'antisocial' plant (Chao 2018: 622, 636, 640). Similarly, my earlier study on forest land disputes in upland Java discussed pine trees growing in state forestland and showed how pine trees are considered hostile by the Javanese peasants. Pine trees are considered greedy for water, pine leaves make land dry and prevent goats from eating in the pine tree plantation, and access to the territory is restricted to villagers working for the state-owned Perhutani Forestry Corporation or foresters (Lounela 2009). While Chao's perspective shows the importance of plants in terms of how people experience their existence within the landscape, my approach complements the ontological turn in that I stress the (anti)relational qualities of the commodity plant in the context of territorymaking, including the boundaries within the landscapes (Sheridan 2016: 30).

Commodification of plants introduces new qualities to socio-natural relations, thereby transforming other-than-human landscapes. As argued by Nancy Peluso:

Once commodified, an object, idea, or part of nature takes on a new life. Newly or regendered (or racialized, or spatially differentiated) practices and relationships also tend to emerge at moments of transformation from predominantly non-capitalist to capitalist relations (Federici 2004). However, the forms and extents of what will change in entangled webs of social and socio-natural relations are not pre-determined. Which configurations will become normalized? These periods-or transitional momentsdo for history what borders do for territories: they create temporal or spatial zones of ambiguity, compromise, and change. (Peluso 2012: 8)

Changes and ambiguities resulting from the commodification of nature connect the making of boundaries and relations with new temporalities and rhythms of life. As Peluso noted, this is also a question of what becomes normalized in the transitional periods. Some commodity plants, such as sengon in Sei Tobun, start their life solely as commodities. On the other hand, rubber trees are at the same time fictitious and market-based commodities, since it is the latex that is made into a commodity, not the trees (Peluso 2012: 8).

Commodification of nature with commodity plants and the making of territories comprise a critical topic, given the changes and rapidly expanding plantations and destruction of the environment in landscapes all over the world, and especially in Indonesia (Lounela 2019). Landscapes are formed of materialities, such as plants, and human and non-human actors, which I take to be agents in the making of socio-natural landscapes (Tsing 2005: 29). Landscapes of subsistence practices, especially hunting and gathering, are embedded with intimate (historical) knowledge and memories (Ingold 2000: 111), but in Kalimantan, 'vegetal politics' (Head et al. 2014: 863) and transformations caused by transformative human agency and new boundaries erase these practices (Lounela 2019). Besky and Padwe 
(2016) suggest three domains of territory involved: legibility and surveillance, ordering and classification, and exclusion and inclusion. Taking these domains as my starting point, I suggest taking plants as participants and agents, rather than objectified resources, as they used to be represented in political ecology studies, thus acknowledging the role of non-humans and their qualities in the making of the territory.

The village of Sei Tobun is located on the edge of peatlands. It covers about 16,000 hectares along the Kahayan River in the southwestern part of Kalimantan. In the 19th century, groups of Ngaju Dayaks settled along the small rivers crossing the large Kahayan River into the swamp forests and formed small settlements there (Lounela 2021). Later on, these settlements became united as one village. The Ngaju form the largest Dayak group in Central Kalimantan (Knapen 2001), but they used to refer to themselves according to rivers (e.g. in my field site N. Uluh Kahayan). Since 1997, fires have recurrently destroyed the forests-and, in recent years, gardens - while also degrading the peatland. This degradation opens up the territory to the introduction of rehabilitation and reforestation projects of often non-native tree species and plants. Of the 15 million hectares of land in the province of Central Kalimantan, about 2,6 million are swampland, which has been or currently is waterlogged landscape. However, the water flows in the peatland have changed due to decades of large- and small-scale drainage and deforestation, and, more recently, rewetting projects, which have crucial effects on how commodification might take place and what can grow in the landscape. In the 1950s, the independent Indonesian state dug largescale canals (polder and anjir) with the help of the Dutch to facilitate transportation and establish rice estates; this had a significant effect on the local cultivation systems (Schophuys
1957; Kop et al. 2015; Tempo 1979). Soon after President Suharto stepped into power in 1967, large-scale timber logging took place in Sei Tobun and Central Kalimantan and 'erased' the natural forests, also producing new drainage and dam systems, because people needed to transport logs through the swampy forests to big rivers (Lounela 2019). The large-scale forest logging and new waterways changed the human-nature entanglements and livelihoods of the local populations along the Kahayan River. In 1995-1997, a large-scale agricultural rice project (Mega Rice Project) devastated most of the remaining forests and produced a massive network of large and small canals to drain the peatland (McCarthy 2013; Muliany and Jepson 2015; on this village, see Lounela 2019). In order to fix this environmental destruction (Castree 2008), the state has initiated multiple forestry and peatland restoration schemes and projects, producing overlapping zones.

This article is based on ethnographic research in Central Kalimantan and in the village of Sei Tobunin 2014-2019. I stayed in the village five times, with each period lasting from one to three months. I also conducted two short-term research periods in Palangkaraya and in a Ngaju village located along the Kapuas River in 2012 and 2013. I focused on five central neighbourhoods, for the reason that I could quite easily walk from house to house in the old 'centre' of the village. Since 2014, my research questions concerned contested values regarding climate change disputes, and since 2018 on emerging water vulnerabilities among the Ngaju people and the commodification of nature and state formation. My ethnographic field research was influenced by the two large-scale fires that burned peatland and forests, causing multiple hazards in the village in 2015 and 2019, pushing me to look at the roles and qualities of different species in their relation to and engagement 
with humans (see Head et al. 2014; Kirksey and Helmreich 2010; Tsing 2015). I talked with tens of mainly Ngaju villagers, but also people that have moved in, including river heads and their families, forest peasant organization members, rubber traders and cooperation actors, and village officials, including the village head and secretary. I interviewed state officials and organization actors (Peat restoration project; REDD+, NGOs) at the district, provincial, and central (Jakarta) levels, and participated in different events. However, in my everyday life I dwelled along the Kahayan River, where I shared everyday life with families in their wooden houses.

\section{ANIMATED NGAJU}

\section{LANDSCAPES AND FORMING TERRITORIES WITH PLANTS AND RIVERS}

The inhabitants of Sei Tobun-about 2,700 people today-were originally Ngaju Dayaks. Earlier, the settlements (N. lewu) along the small rivers (N. saka or sei) consisted of just a few houses inhabited by Ngaju families. Behind the settlements there opened the wet swamp forests, into which people travelled with small boats to collect wild latex and other forest products, to hunt, or to do shifting cultivation (Lounela 2021). The Ngaju have a bilateral kinship system, which means that matrilineal and patrilineal lineages transfer rights flexibly. A Ngaju man (about 60 years old) from a large family that originated from the central part of the village, who also acted as the head of the canal group, told me that when he was young, different settlements were located along different rivers with only a few people and the atmosphere was scary (I. angger). The villagers welcomed people from elsewhere to live there to make it lively (I. ramai). Historically, the Ngaju villagers inhabited longhouses along the large Kahayan River or smaller huts along the small rivers.

The Ngaju cosmology and Kaharingan (local religion) belief entails nature being governed by spirits and ancestors that inhabit the cosmos, which is divided into upper and lower worlds, equated with upper and lower rivers, besides the world inhabited by the people (see Lounela 2019; Schrärer 1963). The Ngaju engage in exchange and sharing relations with the spirits and ancestors to ensure well-being and guard access to their territories (Lounela 2019; Jay 1993; Schiller 1997; Schärer 1963). Spirits dwell within the landscape, and animals may be deceased ancestors. Some animals can be considered 'transformed ancestors' (Béquet 2012); for example, crocodiles can be spirit animals or deceased ancestors, who may again take a human form. These transformed ancestors have an important role in 'protecting' the Ngaju and their settlements, but they also guard 'their' territories (Lounela 2019:58). Despite many Ngaju converting to Christianity or Islam, many in Sei Tobun still hold these ideas to some degree.

In the $19^{\text {th }}$ century in South Kalimantan, when the Dutch tried to gather the Dayak people in permanent settlements along the Kahayan River, they pushed the indigenous groups to mark their land; in this way, the Dutch could expand their activities further inland without land conflicts and collect taxes (Lounela 2021; Knapen 2001). A seventyyear-old Ngaju elder, Pak Esep, whose ancestors' bones were buried in the small house (N. sandung) and who claimed direct genealogy to the founders of the long house (N. buma betang) in the village, told me: ${ }^{4}$ 
Their relatives [I. saudara], the ones who opened the river, obtained land on the left and right side because they opened it, according to customary regulations [I. adat]. It [the river] was continued [I. sambung nyambung]. During the Dutch and Japanese periods, they planted cassava [I. ubi kayu]. When cassava was over, the rice cultivation season started, and they planted dry rice [I.padi gunung]. After that, they planted cassava, harvested, and only then planted rubber. $(28.10 .2019)$

Many elderly Ngaju described how the villagers and later debt-bound Madurese extended small rivers deeper into the forest by manually digging the peatland. The Ngaju dug small ditches (I. parit) to make boundaries between the plots of different kin members, or sometimes a family would keep plots as common property, sharing different rights to the harvests. Later, cassava and dry rice were planted in turns.

The Dutch brought alien rubber plants (Hevea brasiliensis) to Kalimantan in the early 20th century, and they encouraged its cultivation in the estates to replace the wild rubber trees in the swamp forests from which the Ngaju had collected latex (Gutta percha). The villagers remembered that the Dutch restricted local plantations to limit competition in the markets, ${ }^{5}$ reflecting the policy of the government to restrict the collection of native latex in 19101913; later it would impose 'punitive export taxes' on the local commodity rubber smallholders (Dove 2011: 34). However, villagers were free to plant rubber after the independence in 1949. In Sei Tobun, the Ngaju planted alien rubber trees, thus marking their long-term rights, as is often the habit in Borneo (see Dove 2011: 111). They estimated that in the old rubber gardens, one could find trees that are 70-100 years old.

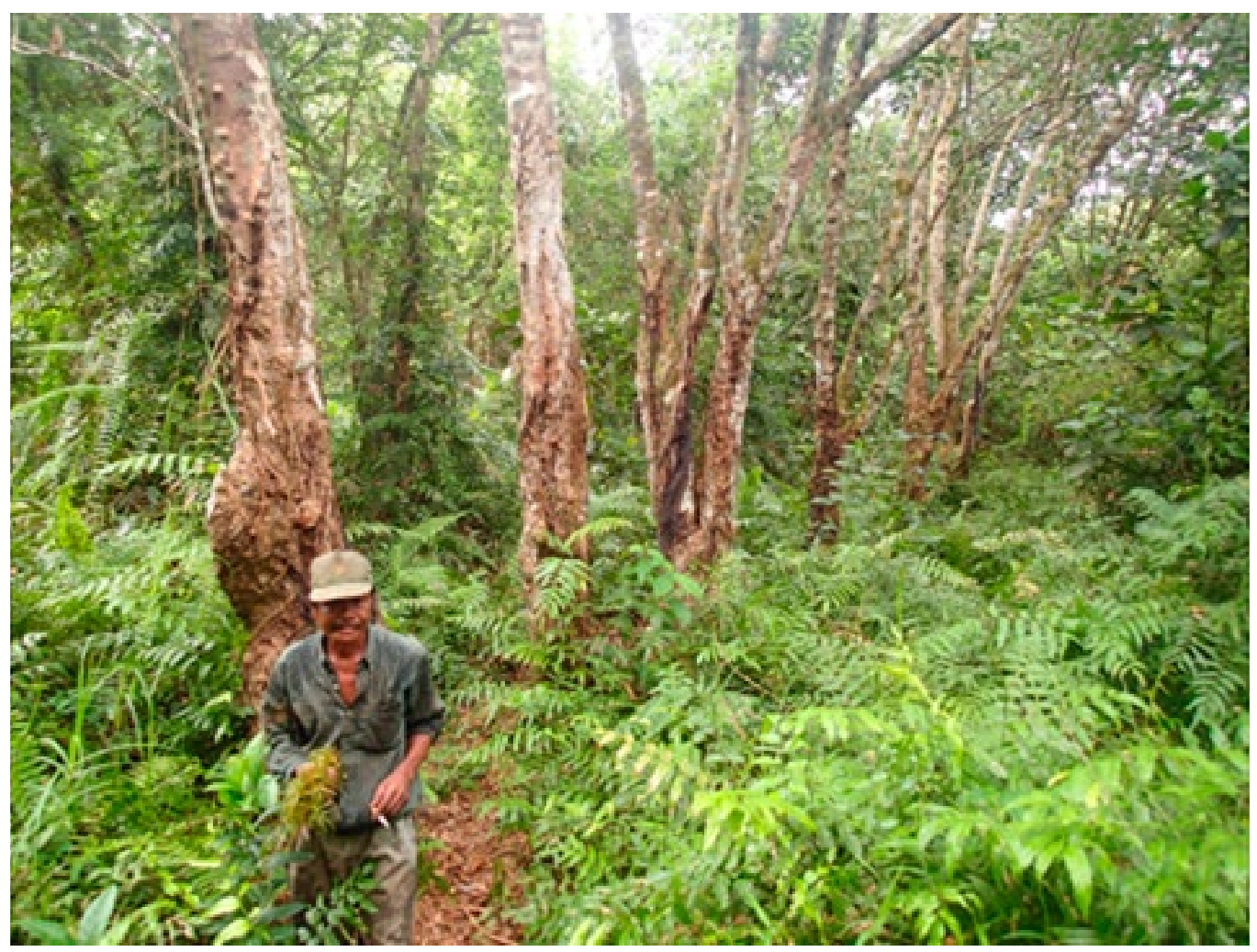

Old rubber gardens in the village. Photo: Anu Lounela. 
This situated history of rubber cultivation shows that the Dutch colonial policies and the Ngaju practices were merged, and alien rubber trees were flexibly adopted into the local cultivation system. Today, the rubber tree (N. batang gita) has positive moral value, even though it had somewhat violent histories in West Kalimantan and involved small-scale slavery (of Madurese) in Central Kalimantan; this can be compared, for instance, to Congo or Brazil, where rubber had a bloody and violent history of terror and slavery during the colonial period (Peluso 2012: 26-27).

Michael Dove has described in detail the rubber plantation economy of the Kantu people in West Kalimantan (1993; 1998; 2011). When land was still plenty, the Kantu combined rubber cultivation with swidden rice cultivation. These two agricultural practices and economic spheres (subsistence and market economies) complemented each other, forming what Dove has called a dual economy (2011: 145-146). Among the Kantu, the rice cultivation cycle comes to an end in about three years and afterwards they plant rubber. Rubber trees cover the land, giving a limited amount of space to other (tree) species and preventing swidden rice cultivation. When rubber replaces the swidden, the Kantu say that 'rubber kills the land' (ibid.:146), taking it out of the subsistence cycle.

In Sei Tobun, the Ngaju marked territories with rubber and integrated it into their livelihood system, while they continued to gather forest products, fish, hunt, collect rattan and so forth, consuming part of the harvest but sometimes selling part of it. My neighbour at the village, a middle-aged Ngaju woman with two children, had married a local man in the 1990s. She told me that at the beginning she was very bad at tapping rubber, that is, making the cuts with the knife (N. mandau) on the bark of the rubber tree. She was given a bad tree so that she could train her skills under the guidance of her mother-in-law. The old rubber gardens are deeply relational and intimate spaces, as one develops an intimate relationship with trees, tools, and plants (Ingold 2011: 56). She and her husband walked a couple of times a week many kilometres to the rubber forest to tap latex, and often their children came along, learning to tap rubber. On the other hand, villagers also have sharing systems in which the employed rubber tapper gets half of the harvest; the share had lately risen to $2 / 3$ for the employed, since it is more difficult to find tappers and because of the commodity's lower price. The tappers used to be Banjarnese or Madurese living in the village, and poor Ngaju villagers and youth were also employed. The Ngaju often go to their rubber gardens as couples after sunrise and return home before midday. During the dry season, they might tap rubber trees a couple times a week. In the rainy season, they go to the garden when it is not raining (when the trees are dry). One neighbourhood had developed a habit of tapping rubber at night because there were too many mosquitoes during the day and, as I was told, due to the greater quantity of latex they got that way. Economically, rubber tapping provides weekly monetary (even if sometimes low) income and relatively equal distribution of the work, income, and access to land (see in comparison Nygren 2005) and in terms of values, autonomy, since the people may control their work time and resources (Lounela 2020).

A Kaharingan customary head (I. mantir) told me that one could give offerings to the spirits to ensure good latex and access to the territory they inhabit, as it is also their place; this points to sharing and reciprocity relations (see Lounela 2017). The landscape is morethan-human, the spirits dwell there. At night, one can see spirits in the trees, one man told me. Old rubber gardens are multi-species more-than 
human territories. One may find, for instance, rattan, bamboo, and other hardwood tree species. One can collect mushrooms or tubers there, and fish in the rivers. Thus, old rubber gardens have become more complex over time, and they contribute to both the market economy and the subsistence economy. If compared to the old swamp forests where people used to collect natural latex, these gardens are legible and simplified forests, contributing to the new social forms and authority systems (Lounela 2021; Peluso 2012). However, they also form affective and relational territories, resembling the rattan gardens of the Katingan Ngaju, who despite the decline of the rattan gardens keep them for non-monetary reasons, partly because they are spaces of human-spirit-ancestral relations (Schreer 2016: 142).

\section{RUBBER AND NEW CORPORATE SOCIAL FORMS}

In the 1960s, the transmigration programme brought Javanese to the village. Pak Esep told me that President Sukarno's government asked the villagers to surrender part of their land on the opposite side of the river to the Javanese, which they did. The Javanese inhabited the area where waterways were made for their wet rice cultivation. For many decades, Banjar people coming from South Kalimantan have married the Ngaju or worked for them in rubber cultivation. Furthermore, at least since the 1940s Madura people have moved to the area, escaping poverty and famine on their home island, today part of the province of East Java, to work for the Ngaju elite as cultivators and tappers. They formed small settlements in the forest, of which there is no trace left today. Today, some Ngaju people are worried that they will soon be outnumbered and they will become a minority in the village.
A local elder told me that the local government and the newly chosen governor Teras Narang (in the position 2005-2015) proposed that villagers expand access to swamp forestland by digging the rivers with excavators and making proposals for rubber planting to the regional government. The governor's mother was related with the village of Sei Tobun, so the Ngaju villagers felt closely related to him. This was the first time they used big machines to make the rivers longer. New, more formal canal (I. handel) groups were formed. While the former river groups (I. sungai) had been based on kin relations with specific inheritance and land tenure rights, the new canal groups distributed land so that people outside the kin group could ask the head for land, and ideally each person would be distributed at most 1-2 hectares. In general, the handel group head distributed the blocks of land first to his descendants or other close relatives near the old rubber gardens. After that, 'outsiders' (e.g. employed rubber tappers) were given land plots further from the settlement in the deeper peatland. Furthermore, Pak Esep told me that village staff could ask for their 'part' (I. jatah) of land since they had formalized the land distribution. This land distribution expanded sociality so that not only the family of the river owner, but also others were accorded access to land; this was a remarkable change, since it alienated land and newly planted rubber trees from the local social relations. Later, in some handels, land plots started to be exchanged for money, bringing further complications, accumulation of land, and changes to social forms and also landtenure systems. (Lounela 2021.)

Villagers soon realized that the distance from the settlement to new rubber estates complicated rubber cultivation and tapping. During the rainy season, the small mostly unpaved roads along the canals became muddy 
and slippery (in my experience, it feels like a dangerous drive). The Ngaju had previously used small wooden boats to travel to the garden sites along the canals, but this demanded following the water flows in the rivers. Some people preferred motorcycles, as not everyone had a boat anymore. ${ }^{6}$ Thus, many bandel members and people asked for narrow asphalt or stone roads along the canals.

Planting new rubber trees and digging the canals were villagers' territorial strategies to expand and stabilize access to land after the the mid-2000s, when the palm oil corporations started to expand and plant palm oil in the nearby areas in the Pulang Pisau district without proper permits, that is, illegally (see, for instance, Rondonuwu et al. 2021). Thus, many Ngaju villagers reterritorialized the land out of fear of the large-scale palm oil plantations (see Lounela 2019; see also Tammisto in this issue). These territorial strategies changed when the fire disasters opened the state land to new state territorialization, that is, social forestry schemes.

\section{STATE LAND,} TERRITORIALIZATION, AND (IL)LEGIBILITY

Vandergeest and Peluso discussed territory as an aspect of state control and state territorialization as a process whereby the modern state extends control through administrative and governance techniques over a specific geographic area, resources and population (1995:387). They introduced the concept of internal territorialization' (ibid.: 386), pointing to state administrative and governance practices that produce overlapping systems which complicate the local land tenure systems and environmental practices by producing new boundaries and 'resources', as well as overlapping claims to them within the nation states. For instance, in
West Kalimantan, internal territorialization and simplifications by the state actually complicate the local land-tenure systems by adding a new layer of relations and overlapping boundaries within the landscape (Wadley 2003: 93), as in the case of Sei Tobun.

The state creates legibility through abstract categories and representations, opening the landscape for producing territories and transforming nature into resources and commodities, pointing to the recent scholarly discussion that 'frontiers represent, most basically, the invention of new resources' (Rasmussen and Lund 2018: 388). In frontiers, the rapid and wild transition of the physical place has huge effects on human-nature relations: contradictory state administrative practices, unclear enforcement of legislation, and actors extending control to mark territories, while messy state and non-state governance and legal systems overlap with each other (McCarthy 2013: 183). However, I would stress that in Central Kalimantan, the category of state land creates frontiers for capitalist development (Kelly and Peluso 2015; Lounela 2021).

In Indonesia, plants (e.g. forests, plantations, crops) mainly grow on 'state land', which covers the majority of the land surface (120.6 million hectares). They are further divided into different subcategories, such as production forest, protected forest, and conservation forest (Ministry of Forestry and Environment 2018: 7). Kelly and Peluso (2015: 474) have defined state land as that over which the government claims the right of control. ${ }^{7}$ In Indonesia, the state land definition brings areas under the control of the central government or, in terms of smallscale land use permits, under the control of the regional government. The historical genealogies of state formation date back to the colonial period when the Dutch rule designated large areas as wasteland, a category which was further 
strengthened by various legislative bodies of independent Indonesia (ibid.: 484-488).

Central Kalimantan is the third-largest province in Indonesia. State land comprises about 80 percent of the total land area. According to Indonesian Friends of the Earth, 74 percent of the state land has been licensed through permits to different plantation or mining corporations. The Central Kalimantan province exemplifies an administrative unit where large tracts of state territory make it possible to convert land to commodity (plant) production through different state and non-state actors, who often belong to corrupt networks of power that gain economic benefits from these processes (see Aspinall and Berenschot 2019).

The making and un-making of frontiers often include the removal of previous rights (e.g. customary) and plants (e.g. swamp forests) from landscapes (Tsing 2005: 68), as well as the

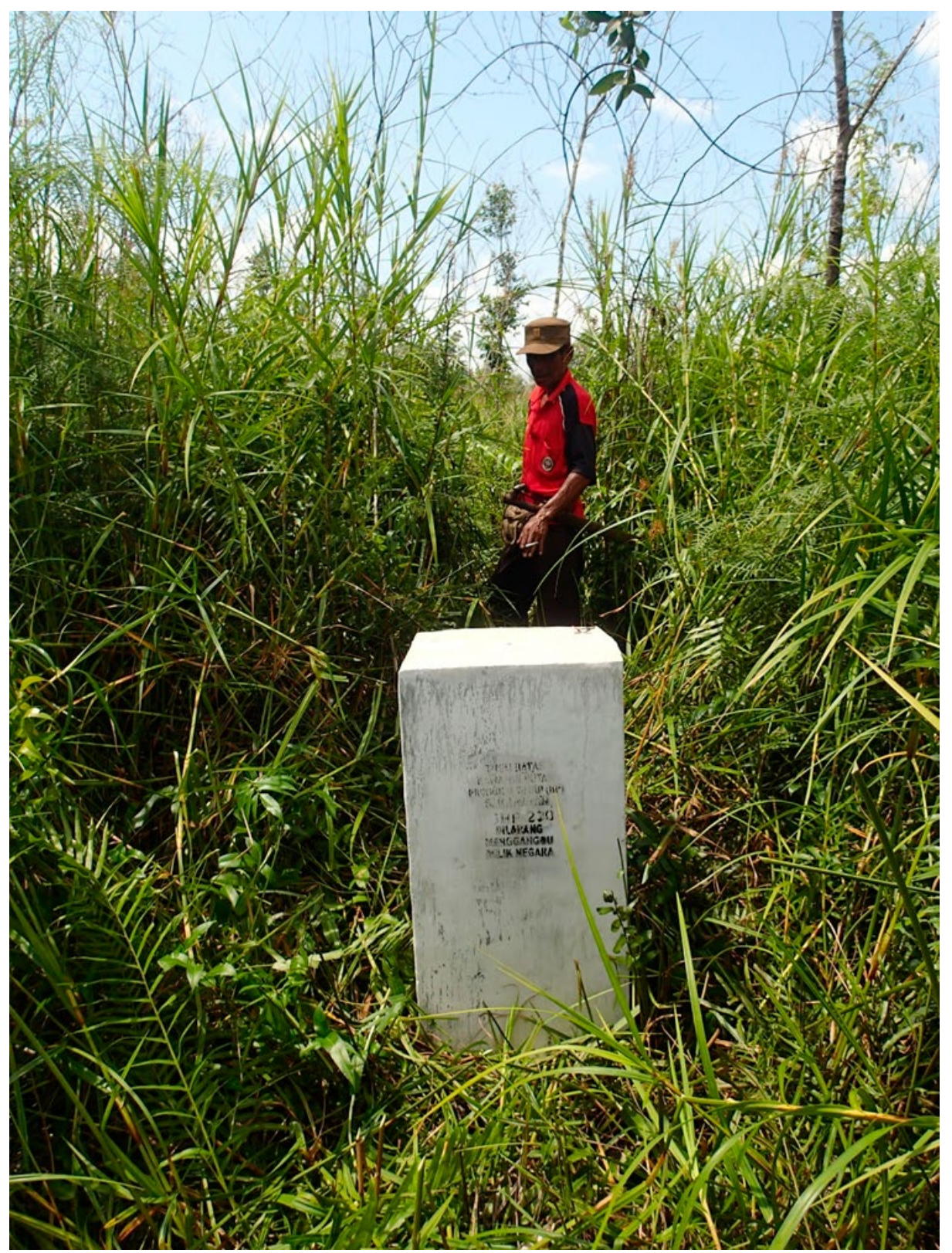

A Ngaju man looking at the state boundary marking pillar. Photo: Anu Lounela. 
erasure of intimate relations with and memories of that landscape (Lounela 2019), and replacing them with new ones. For the degraded peatland (here an already logged and burned one), it is fire that empties the landscapes. In 2015, approximately 429,000 hectares (16 percent) of the forest and land were devastated in Central Kalimantan. About 33 percent of these forest fires spread in peatlands that comprise a specific type of swamp forest landscape (World Bank Group 2016). In Sei Tobun, about 40 percent of the predominantly young rubber trees burned in large-scale fires in 2015. Many Ngaju people spent weeks or even months guarding their trees from fire; some people were injured.

State territorial projects extend to these emptied territories, bringing along forestry schemes. State territorialization in Central Kalimantan is a question of politics of value where territorial processes are concerned (Lounela 2020; Graeber 2001).

In 2016, after the fires in 2015, the Ngaju people in Sei Tobun were extremely worried about state officials coming to the village and asking to mark the boundary between the state forestland and the land under their ownership with white cement pillars. In the village of Sei Tobun, the state land includes protected forest (8,804 ha), production forest (2,459 ha) and land for other use (APL, or Area Penggunaan Lain) (Profil Desa dan Kelurahan 2017). Furthermore, 7,025 hectares of the protected forest area have been granted village forest area status (I. hutan desa), which means that people have access to land, but their management practices are restricted to non-timber activities. Today, the village forest area is also called a social forestry scheme, which was initiated by the villagers with NGOs in order to stop palm oil companies from expanding onto village land (see Lounela 2019).
The villagers knew that there is state land in the village area. That was the reason they had made a deep canal (I. kolektor) to cut across the handels in land that they considered the protected forest area, located about six kilometres from the settlement on the west side of the Kahayan River. It was obvious that the villagers believed that their land rights extended much further from the settlement than what the state officials considered. My discussion with the village head indicates how difficult the issue was. This, quite young, Muslim, village head had been elected to the position in 2015 . He was an unexpected choice, since his interests lay elsewhere (e.g. gambling) and he did not campaign, unlike the other four candidates. $\mathrm{He}$ told me he had escorted the administrative staff to the forest to mark the land:

Village head: Frankly speaking, I am not going to forbid the government programme. I do not want to be mixed up in this. Well, it is not clear to me. I do not even know the boundaries of the protected forest and the production forest. How many kilometres from the village the boundary is located, I do not know. We have heard that the kolektor [the deep ditch dug with an excavator to mark the boundary six kilometres from the Kahayan River] is a buffer forest [zone]. Nevertheless, [I don't understand] buffer forest from which forest-production or village forest or protected forest?

A: How about people's gardens. Are they located in the production forest area? Village head: They are located below it. Now they say it is a production forest. The village secretary told me that the production forest has been there from the Dutch colonial period. If we look at it now, 
after hundreds of years, we don't see the [state] forest. Because it is managed by people. (29.4.2016)

The village head is a representative of the state in the village. His role is to initiate the operation of state projects, which in remote areas such as Sei Tobun often means facilitating development or industrial extraction project ventures. Being both a member of the village community and a state representative often means balancing between the two, but village heads often look for personal advantage of new projects, as well.

James Scott (1998) has proposed that legibility is a fundamental concept for statecraft: the state needs to create legibility by simplifying local complex practices in abstract grids to extend its power over territories and populations. The concept of 'legible', as proposed by Scott, refers to the ways the state and its 'officials took exceptionally complex, illegible, and local social practices, such as land tenure customs or naming customs, and created a standard grid whereby it could be centrally recorded and monitored' (1998: 2). Thus, legibility is necessary for taking control over nature, land, and populations, even in the remote 'frontiers'.

Marking the state land area with cement pillars is part of the territorializing process on the margins of the state: rather than creating legible landscapes in the frontier conditions, it produces new forms of illegibility through messy territorial practices and overlapping and contradictory state legislation and networks of power (Das 2004: 227). The village staff often do not have accurate knowledge of the boundaries and the legislations ruling them, which actually helps the state or corporation territorial projects to expand into remote areas. In the next part, I explore the role of plants in the production of forms of illegibility in the making of territories.
SOCIAL FORESTRY: TERRITORIALIZATION, (IL)LEGIBILITY, AND NEW TREE SPECIES

The insight that projects of state territorialization are simultaneously resource control strategies help us to see how plants-their arrangement upon the landscape, the uses to which they are put, their incorporation into markets, their meanings-become enrolled in territorial projects along contested agricultural and resource frontiers. (Besky and Padwe 2016: 14)

Besky and Padwe (2016:14) suggest that in terms of plants, there are two important strategies to create legibility in Scott's terms: scientific forestry and high modernist agriculture. Monocrop plantations and estates would be the extreme cases of such legibility creation projects. Michael Dove has discussed plantations and estates in Borneo as prime examples of creating 'panopticon-like legibility' (2011:51), showing the power and limits of power of such estates. Thus, legibility is about incomplete state rule extended to localities through (plant) projects that aim to control, albeit often failing ( $\mathrm{Scott}$ 1998). Consequently, illegibility is an important locus of statecraft. I wish to show here how illegibility informs territory-making through capitalist monoculture plant expansion.

In 2015, President Joko Widodo and the Indonesian government started an agrarian reform programme, which includes a social forestry programme with five different schemes (see The Ministry of Environment and Forestry n.d.). Agrarian reform is supposed to cover 21.7 million hectares of land, of which 16.8 million hectares are forest land (state land) in Indonesia. The agrarian reform programme (TORA) distributes private ownership rights to 9 million 
hectares of land, while the social forestry scheme that covers 12.7 million hectares grants usufruct and management rights to the state forestland to communities (Resosudarmo et al. 2019: 1). In Indonesia, social forestry has taken many forms at different times since the 1980s. Especially in Java, it has been a policy to integrate 'forest peasants' as labour in the management of state forest land and extend control to remote upland and forest areas to convert nature into resources through what could be called soft techniques (Lounela 2009; Peluso 1992).

Different schemes under the social forestry programme relate to different categories of state land. In 2013, for example, Sei Tobun was granted the status of a forest village area (butan desa) that covers about 7,000 hectares. It is currently considered a social forestry programme, but because this scheme covers the protected forest area, the villagers can only engage in non-timber activities, such as fishing or collecting forest products; they cannot cut timber. ${ }^{8}$

The new social forestry programme under President Jokowi's 'land reform' differs from the earlier ones in that it promotes social forestry with private businesses as a third party. In the district of Pulang Pisau, the programme became linked with the opening of the Naga Buana plywood factory in 2016. ${ }^{9}$ In relation to its inauguration, the minister Siti Nurbaya gave a statement in the newspaper that the social forestry programme aims to develop the timber industry and small-scale enterprises (Lensa Kalteng 2016).

The Naga Buana plywood factory was built on land located on the opposite side of the Kahayan River from the settlement. This used to be a place where people had cultivated rice, before planting rubber trees and rattan there. The villagers told me they sold their land, as demanded by the company. Some people had tax payment certificates proving their land ownership (although these are not legally sufficient proof), while others probably had proper land certificates. But if they did not have those, the villagers stated, they got assistance for the certification processes from the company. The staff from the village office estimated that maybe 400 hectares were sold to the factory. Illegibility is an inherent part of the land acquisition process; in my understanding the corporation cannot buy land, but a private person buys the land in the name of the corporation. However, villagers I discussed this with thought they sold the land to the corporation.

When he opened the Naga Buana plywood factory in the location in 2016, President Joko Widodo gave the Sei Tobun village head a certificate that legalized the social forestry programme HTR (Hutan Tanaman RakyatPeoples Plantation) and the forest peasant organization GAPOTKAN (Gabungan Kelompok Tani-Association of Farmers Groups) and its sub-organizations KTH (Kelompok Tani Hutan-Forest Peasant Group). ${ }^{10}$ The village head became the head of the organization with six sub-organizations, each having their own organization heads. Villagers were supposed to apply for funds and assistance and organize sengon planting through the organizationsotherwise the villagers might plant sengon with their own funds. However, the HTR scheme raised tensions and conflicts over rights to land with the new forestry peasants' organization. Pak I, the head of one of the canal groups, explained to me that members of his group were fed up with the forestry scheme that expanded onto their land: 
Pak I: It is really so that the people [masyarakat] owned it, the handel owned [land], until the kolektor. There came what they called the HTR. We rejected the HTR, but then we compromised with Lestari [the USAID project in the village]. We negotiated... Saka Jang and Tobun [bandel] were included in the HTR until north it is the HTR [the canals mentioned here are in the northern part of Sei Tobun]. There was a map bought by Pak A from Lestari. The mid handel was included in the HTR, and at the end of the river it was all HTR! Below the kolektor it was part of the HTR... I negotiated with them. I said, why, the handel was here before the HTR.

$\mathrm{D}$ (young man, my assistant from the village): They took it [land].

Pak I: If they want to take the land, take it above kolektor, but this is the people's land. We made rivers that reach six kilometres from the Kahayan River, above it. Up to you if you want to have village land, protected forest, but kolektor is our boundary. Already twice we have deepened kolektor so that water stays up there. The HTR is coming to our/the people's land. (18.2.2019)

State territorialization through the social forestry project was connected to the marking of state land boundaries, inauguration of the social forestry scheme with sengon plants, and forming a new social institution with new social forms. In the village, this gave rise to tensions because of the related inclusions and exclusions, a point proposed by Besky and Padwe (2016) as crucial to territory-making.

While the state may benefit from the constant (re)invention of resources, schemes, commodity species, and land appropriation, the local populations need to rapidly recreate territorial strategies to maintain their access to territories and mark their rights to the land. In this case, that is done by adopting new statepromoted commodity species.

\section{RAPIDLY GROWING TIMBER: COMMODITY PLANTS HAUNTING THE TERRITORIAL STRATEGIES}

The landscape of Sei Tobun is formed of ecologically specific peatland. The swamp water is acidic, and its flows in the small rivers depend on seawater, which affects the movement of water in the Kahayan River. Peat is poor in nutrients because it has been formed from trunks, branches, leaves, and so forth. Human activities in waterways, as well as cultivating and collecting forest products, tree planting and management, make this southern part of Central Kalimantan a very specific ethnographic place and environmental wetland landscape (see Krause 2017).

To tackle the peatland fires in 2016 President Joko Widodo inaugurated the Peat Restoration Project (BRG), which appeared to replace the previous REDD+ climate change mitigation projects (favoured by the previous president, Yuodhoyono Susilo Bambang). In 2017, the BRG started its rewetting project in the village and Central Kalimantan. The BRG employed local people, or alternatively third parties (e.g. universities), to build small dams to block the small canals in zones that people now considered their land and where they had actually planted sengon trees after the fires in 2015. While there is not space here to go into detail on the dam-building project by the $\mathrm{BRG}$, the outcome was that during the rainy season, the water level rose so much that large parts of the newly planted sengon trees were inundated by water. Thus, many seedlings died or did not grow well. It is interesting that the 
BRG project was linked to the social forestry scheme (HTR) inaugurated along with the Naga Buana factory; for example, in the neighbouring village, the BRG head visited the 'economic revitalization project' site that focused on sengon planting and also the Naga Buana factory in Sei Tobun (Prahara 2019). Pak I (the canal head) told me angrily that, at first, the BRG gave them the canal-blocking R1 project (rewetting of peatlands), but then they failed to give the following R2 (revegetation) and R3 (revitalization of local livelihoods) projects, to get access to land and the planting of plants that can withstand water.

Pak I: Only five hectares of sengon trees are left. After 2015, almost nobody planted rubber. Many did not plant anything. They suffered from trauma with fires...

A: What are their livelihoods then. Do they do gardening?

I: There are only a couple people who live from rubber tapping [in Saka Jang canal], maybe five people who are tapping young rubber in the gardens. Some people do not want to tap, and they become labourers (I. tukang) or they work in the factory [Naga Buana]. Those who put their hopes in the land have become only a few; they have to search for work in other places. I see the same with almost every river ... Instead of planting rubber, they plant sengon [if anything]. They say: in five years we get income, but rubber is killed by fire...

A: Do they cut sengon when it is still young?

I: Some cut a tree when it is only $14 \mathrm{~cm}$ in diameter, which is only a couple of years old! Very young! They want to have money fast. (18.2.2019)
Villagers wanted to plant sengon because they were encouraged to do so by the President and the Ministry of Forestry in the course of the inauguration of the social forestry (HTR) programme and the plywood factory. Many villagers assumed that devastating fires erupted at least every five years and sengon trees could be sold before the next fires, while rubber trees could be tapped only when they are about six years old. Considering the recurrent fires that had devastated the rubber gardens, shifting to other tree species made sense.

Most of the villagers had no previous experience with sengon trees. They bought seedlings from the traders. The forest peasant groups (KTH) could get support from the forestry department; the head of one of the organizations told that they got 15 million rupiah for buying seeds and planting them and growing them into seedlings. The Ngaju imagined that sengon would make them rich quickly. Thus, some of them cut down old rubber gardens and replaced them with sengon. This is a remarkable change; although old rubber trees were becoming less productive, the rubber gardens were intimate spaces and had provided weekly cash income for decades. The space near the Kahayan River is conducive to sengon planting, though, because the peat is shallow, hard trees grow better, and fires rarely extend there. Thus, there were at least two reasons for this shift: fear of fires that would devastate trees in 4-5 years intervals; and the newly built plywood factory that had promised to buy timber directly from the villagers.

A Ngaju man told me that one needs to care for the small sengon seedlings for their first year of growth, or else the plants may die. After the first year, the plants do not demand much work or care; they are just left to grow. In the deep peat, one needs to use a stick, which 
is pushed into the ground to grow sengon. The seedling is tied to the stick. Otherwise, sengon trees become weak or distorted (N. mabolei). When the seedling grows bigger, the stick will fall over by itself. The Ngaju clean the ground of vegetation and swamp tea-trees (Melaleuca cajuputi, locally called I. galam) before planting. As it is, when vegetation in peatland burns, it destroys part of the peat surface and afterwards the galam trees take over as a pioneer species. Sengon trees are planted at a distance of 2-3 metres apart. The tree density is quite high, and as many as 1,000 trees can be planted in one hectare. ${ }^{11}$ The Ngaju compared this to Javanese sengon plantations, where (to their knowledge) only 600 sengon trees grow in one hectare because the Javanese allowed other species, too (of course there might be other practices among the Ngaju as well). Some wealthier villagers, such as the village staff, or those living elsewhere, could hire Javanese to plant the seedlings. Harvesting sengon was done in two ways: cutting trees in small plots, thereby leaving some plots to grow, or cutting them all at the same time; many preferred to sell them all at once.

Trees are most often sold to the brokers, who come to the village, buy the trees (at a lower price) and sell logs to their bosses. The village staff had the view that it is better to sell timber to brokers since there is always a risk that the timber quality would not be good enough for the company, they would not be paid enough, or they would need to wait for payment. Thus, from what I gather from the villagers' stories, the network of brokers and

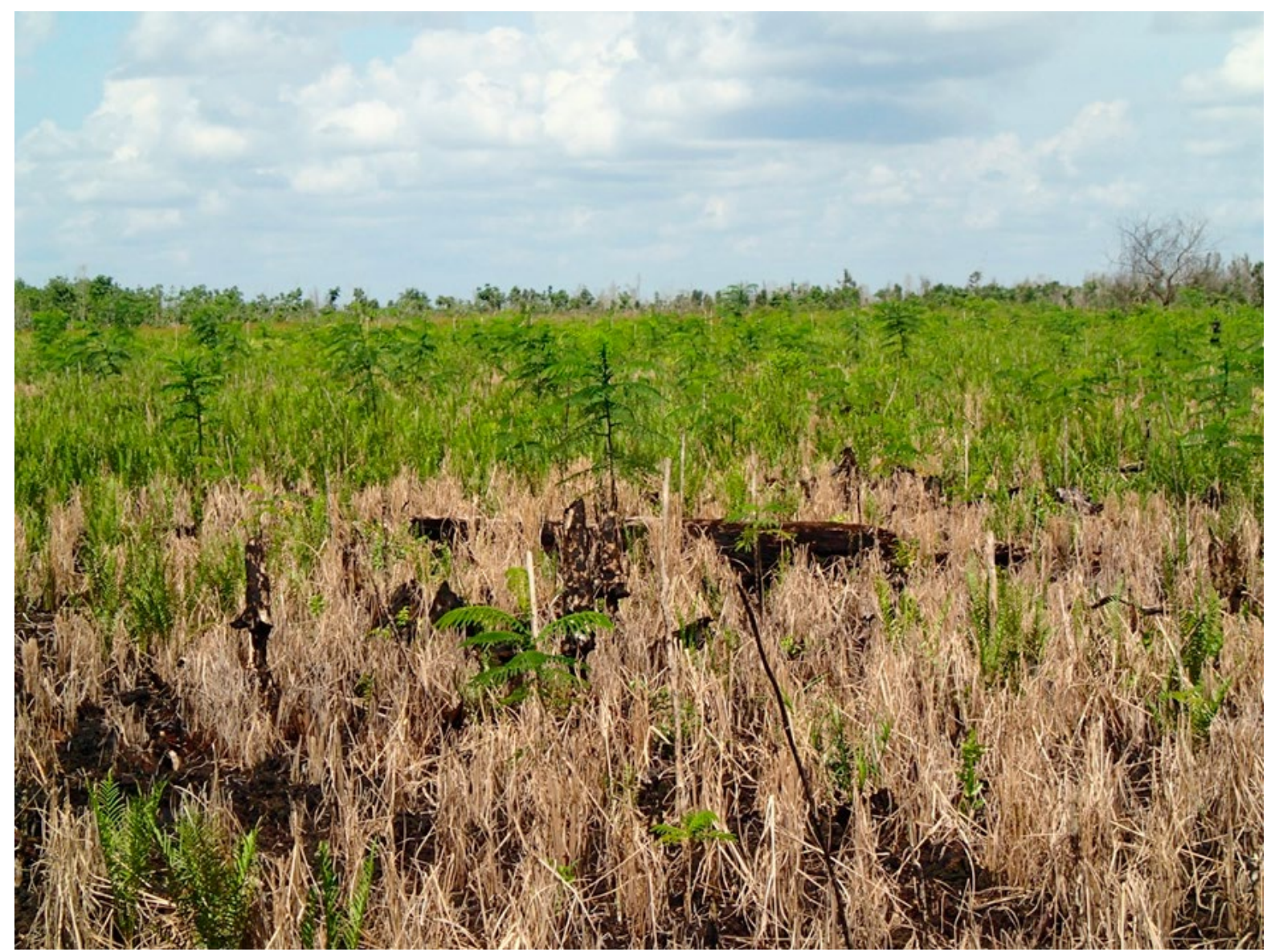

Sengon seedlings growing in burned peat soil. Photo Anu Lounela. 
other actors arranges the buying and selling of the timber. This network determines the price of sengon and mediates between the villagers and the factory, or other buyers, which is not really how the HTR scheme was envisaged in the developers' dreams and plans (Tsing 1993).

Furthermore, sengon is obviously not rubber. Sengon is mainly a monoculture plantation plant in Sei Tobun, and its qualities thus become extremely important. How does it grow in the peatland? How does it handle (acidic) water flows that change seasonally and follow tidal waves? How do infrastructural changes, such as dam-building on the canals, affect its growth? How does it withstand water or drought, or even fire?

In 2019, the dams in the canals built through the BRG project caused the water level to rise so much that large parts of the newly planted sengon trees were inundated during the rainy season. A middle-aged man, the son of an elder who was well known in the village for his knowledge of Kahayan Ngaju histories, and currently the forest peasant organization head, explained:

Peri: The [BRG] programme is good, but it has negative effects.

A: I have heard that some sengon trees were inundated.

P: If I have one hectare of sengon trees like my friend does, his sengon trees were already high... Part of them died! The process is that not all of them die at once. They die slowly. The leaves start to fall and they become dry. Sengon is sensitive, it is sensitive! But rubber trees are strong [I. kuat]. Even if inundated for one week, it does not matter.

A: If you want to sell them to Naga Buana?

P: Well, if Naga Buana sends sengon to Java for pulp, it can buy anything. Even branches can be accepted, wood is crushed. But if they want it for plywood, they want big ones. (18.1.2019)

In January 2019, water flowed into the people's new sengon plantations, with some of them becoming like 'lakes'. Consequently, the sengon trees turned yellow or just died. Some people worked hard to build drainage to save the trees, but this was a very difficult task, especially when the plots were located more than three kilometres from the settlement. Villagers were unsure if they could sell the trees to the factory. However, most of them did not have time to sell them, since later in 2019, the fire disaster spread a year earlier than had been predicted. The fires were almost as severe as they had been in 2015. Beyond the old rubber gardens, sengon trees burned and died. It turned out that fire kills sengon immediately; it becomes fuel for the fire. Villagers had an experience of rubber trees, which can recover from a small fire, but the sengon trees just died.

The villagers thought of sengon trees as 'savings'. Once when passing a plot of four yearold sengon trees, the men travelling with me in a boat on the canal laughed and said: 'See, money storage!' Villagers imagined that they could 'store' monetary value in sengon trees and, after selling the timber, they could educate their children (this was the reason mentioned most often). However, it turned out that some people sold sengon when the trees were only two years old. This is a remarkably short period in the life span of trees. In comparison, the Ngaju have intimate relations with rubber gardens through their weekly tapping activities. In comparison, the Ngaju have intimate relations with rubber gardens through their weekly tapping activities and the villagers extract latex from the rubber trees with special skill gained through longterm practice. Furthermore, rubber tapping 


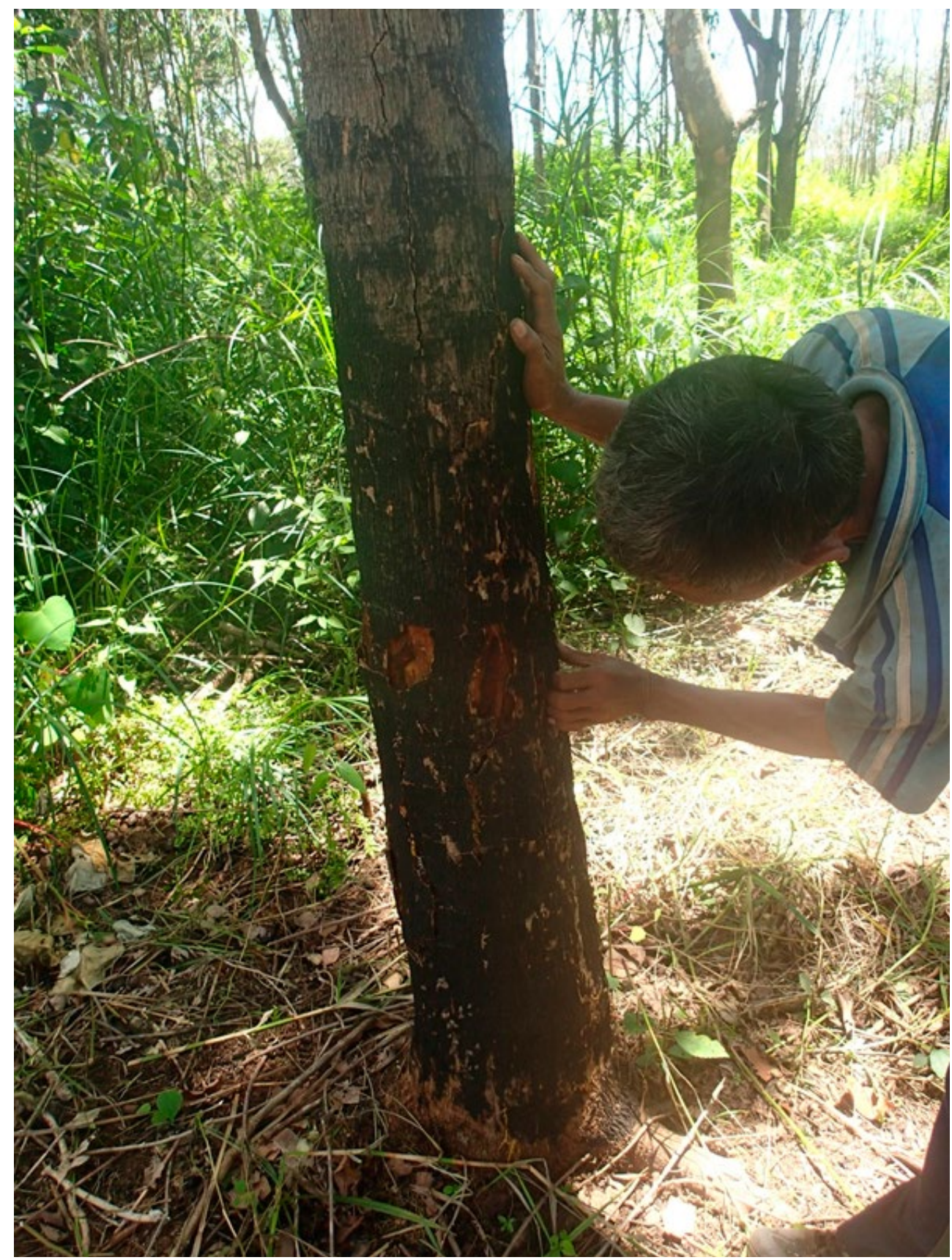

Burned young rubber tree. Photo Anu Lounela.

provides weekly monetary income and relatively equal distribution of the work and access to land through, for instance, the sharing arrangements and flexible access to land and trees. Rubber trees can grow rather old and stabilize territorial relations, unlike sengon trees.

\section{CONCLUSIONS}

In this article, I have explored the role of (commodity) plants and humans in the making of territories, and their qualities within the socio-natural peat landscapes. My article has argued that plants are not merely metaphors 
or resources but participants, being qualitative and unruly companions in the making of territories (Besky and Padve 2016; Tsing 2012; Head et al. 2014). In Central Kalimantan, the Ngaju people interact with different plant species, water, peat, spirits, and humans. Who the agents are in the making of territories and what qualities emerge in these processes are crucial to the lives of the local people and these socio-natural landscapes.

The commodification of nature involves multiple governing institutions and politics at different scales (Rasmussen and Lund 2018: 394). Territorialization involves state, and increasingly also other actors when seeking to extend control and power over landscapes. Commodity plants have an increasingly big role in these processes. The Central Kalimantan province is part of the Indonesian state, and a large area of the province is categorized as state land. I have argued that state land is a crucial category in the making and unmaking of the frontiers (Kelly and Peluso 2012) and invention of new resources or transforming nature into commodities (Rasmussen and Lund 2018). Sometimes contradictory (customary, regional, national) legislation and messy implementation of laws opens the province for overlapping territorialization processes that involve commodity species with different qualities.

The Indonesian government's agrarian reform programmes extend territorial projects such as social forestry in this shifting frontier. Partly adopting these strategies and partly creating their own territorial strategies, local Ngaju people planted rapidly growing timber species in the hope that they would be able to produce commodities for the markets after fire disasters threatened their rubber economy. However, the natural disasters (fire) and the ecological characteristics of the landscape (peat land) affect how the boundaries between the local people and the state and corporations become contested and contribute to new forms of illegibilities, of which the social forestry scheme is a good example.

I argue that there are limits to being a commodity producer in the swamp areas of Central Kalimantan. Even though local villagers might periodically be enthusiastic commodity producers and shift to working with new commodity plants, such as sengon, which also become companions in their territorial strategies, the qualities of the plants or their networks (corporations, state actors, market actors, brokers, other species) may surprise or fail them. This seems to differ from Li's description of Sulawesi highlanders, who have a long history of being involved with a market economy, dating at least to the 18th century (2008: 125), and who are 'enthusiastic commodity producers' rather than nature-lovers and tree-protectors. A Sulawesi highlander would not be a 'profligate native', but they can 'turn resources to a profit' (ibid.:127). $\mathrm{Li}$ understands their struggle to be more about the distribution of costs and benefits than about their willingness to be involved in the commodification of nature.

Li's argument is important in that it shows that Sulawesi highlanders adopt commodity plants (e.g. cacao) willingly. However, I have shown that in ecologically fragile frontier areas, such as Central Kalimantan, people choose alien commodity plants, which may become harmful companions (Tsing 2012). The limits relate to the qualities of the plants and landscapes and the illegibilities of the territorialization and state formation (Das 2004). In frontier situations, local people plant commodity plants because they are part of their territorial strategies in rapidly changing situations, contestations, and insecurities concerning access to land and changing possibilities for making their living (Galudra et al. 2010). 
I have suggested that territory can be linked to discussions of the relational, spatial, and temporal qualities and rhythms of the plants in their interaction with humans or as parties in territorial strategies of humans, the state, or others. For instance, the Ngaju had intimate and flexible relations with rubber trees, which could be managed by the family or kin group or employed tappers in complex ways, and in connection with other plants, thus becoming inclusive, long-term, and socially reproductive territories.

On the other hand, sengon trees were introduced to the villagers as rapidly growing timber trees that would have a relatively short life span. Sengon have qualities which the Ngaju could not foresee: they are 'sensitive' to water and fire, they burn easily, and they die when the peatland becomes too wet. In relational terms, sengon trees are not hostile. However, they may become bad companions in the making of territories within the swamp landscape. Further, sengon-human territories are gendered, in the sense that mainly men take care of planting and cutting the trees, and alienated, in the sense that Ngaju couples and families do not have weekly caring and working routines with them. They produce new visual, social, and temporal qualities, making the rhythms different but still being, for the time being, important in the making of territories.

Expansive territorial projects involving the commodification of nature by the state in collaboration with non-state actors, such as corporations and donors, have effects that can make local groups more vulnerable. Paradoxically, the Ngaju people were planting state-introduced trees in an area that they considered theirs, only to realize that in this way it was becoming a state territory and marked as state land. Trees, or plants in general, are important for the state in its attempts to create legible territories embedded with new property rights and labour arrangements. Ultimately, plants are relational and temporal agents, deeply social and with multiple effects on the socionatural relations and everyday lives of the people.

In the context of Indonesia, the commodification of nature is entangled with contestations over different categories of land, access to that land and what grows there, and has a bearing on the qualities of those territories, that is, rhythms of visuality and temporalities, and exclusions and inclusions.

\section{ACKNOWLEDGEMENTS}

I am grateful to the two anonymous reviewers. I especially want to thank one of the reviewers whose comments significantly helped me to clarify my argument. I also wish to thank Tuomas Tammisto and Heikki Wilenius for their fruitful collegial friendship and comments during the 'New regimes of commodification and state formation on the resource frontier of Southeast Asia' project funded by the Kone Foundation. Kind thanks to Anja Nygren, Mira Käkönen, and Pujo Semedi for fruitful discussions throughout the project 'Water and Vulnerability in Fragile Societies', funded by the Academy of Finland (grant 1317319), which made writing the paper possible. Thanks as well to Viola Schreer for her helpful comments.

\section{NOTES}

1 The name of the village is a pseudonym.

2 In some newspaper articles, the sengon trees planted through the social forestry programme are mentioned to be the Albizzia chinensis species. However, the Naga Bhuana corporation webpages mention that it uses Albizzia falcataria species. I recall villagers talking about sengon seedlings that are of different types, some of good and others of bad quality. Since it is possible that villagers plant different kinds of albizzia trees, 
I will just call them sengon trees throughout the article.

3 I will mark Indonesian and Ngaju words with letters: I=Indonesia and N=Ngaju. It is good to note here that I spoke with the Ngaju mainly in Indonesian language, but the Ngaju mixed Indonesian with Ngaju language, and when I was present the Ngaju people would sometimes mix Ngaju and Indonesian when speaking Ngaju.

4 All the names of the people in the article are pseudonyms.

5 This may differ from the Barito River, where people had direct access to the trade centre in Banjarmasin.

6 When young rubber estates burned in 2015, some villagers had a view that the trees and grounds burned because people did not take care of them enough, because the owners lived elsewhere, or they did not have time to manage the new gardens. It was also obvious that it was burdensome or sometimes almost impossible to travel through the peatland to manage the trees, especially after rain.

7 As Kelly and Peluso note, state land is defined in different ways in different countries. In general, however, it is about the formalization of land as state land through practices that 'document, legalize, register, title, and assign property rights in land through bureaucratic means' (2015: 474).

8 Since I have discussed this scheme in more detail in my earlier article 'Erasing memories and commodifying futures' (2019), I will not discuss this scheme further here.

9 The state forest land covers 82 percent of the total $(1,035,910.74 \mathrm{ha})$ with the different subcategories of land of the district (Ringkasan eksekutif. Kajian Lingkungan Hidup Strategis (KHLS) RTRW, Kabupaten Pulang Pisau tahun 2014-2034 2014).

10 The inauguration of the factory, together with the inauguration of the social forestry or HTR programme, was welcomed by the governor, too. See Sahala (2016).

11 In an interview with Rekam Nusantara for our research a villager told us that initially the corporation promised that one tree would be 'expensive' (mahal) or $150000 \mathrm{rp} /$ tree and that it buys any size of trees, but in 2021 the price per tree was only 100000 , and they selected which trees they buy; selling the trees would not cover the costs of planting new trees, hence, the disappointment (Rekam Nusantara 2021)

\section{REFERENCES}

Allerton, Catherine 2013. Introduction: Spiritual Landscapes of Southeast Asia. Anthropological Forum 19 (3): 235-251.

https://doi.org/10.1080/00664670903278387.

Aspinall, Edward and Ward Berenschot 2019. Democracy for Sale: Elections, Clientelism, and the State in Indonesia. Cornell University Press. https://doi.org/10.7591/9781501732997.

Besky, Sarah, and Jonathan Padwe 2016. Placing Plants in Territory. Environment and Society 7 (1): 9-28. https://doi.org/10.3167/ares.2016.070102.

Brighenti, Andrea Mubi 2010. On Territorology: Towards a General Science of Territory. Theory, Culture E Society 27 (1): 52-72.

https://doi.org/10.1177/0263276409350357.

Cambridge Dictionary (n.d.) Territory. Cambridge Dictionary Online. https://dictionary.cambridge.org/ dictionary/english/territory. < Accessed 8 November 2021>

Castree, Noel 2008. Neoliberalising Nature: The Logics of Deregulation and Reregulation. Environment and Planning 40: 131-152. https://doi.org/10.1068/a3999.

Chao, Sophie 2018. In the Shadow of the Palm: Dispersed Ontologies Among Marind, West Papua. Cultural Anthropology 33 (4): 621-649. https://doi.org/10.14506/ca33.4.08.

Das, Veena 2004. The Signature of the State: The Paradox of Illegibility. In Das, Veena and Deborah Poole (eds). Anthropology in the Margins of the State. Oxford: Oxford University Press.

De Jong, Wil 2001. The Impact of Rubber on the Forest Landscape in Borneo. In Arild Angelsen and David Kaimowitz (eds). Agricultural Technologies and Tropical Deforestation. Wallingford: CABI. https://doi.org/10.1079/9780851994512.0367.

Deleuze, Gilles and Félix Guattari 1988. A Thousand Plateaus: Capitalism and Schizophrenia. London: Athlone.

Dove, Michael 2011. The Banana Tree at the Gate: A History of Marginal Peoples and Global Markets in Borneo. New Haven: Yale University Press. 
Elden, Stuart 2010. Land, Terrain, Territory. Progress in Human Geography 34 (6): 799-817.

https://doi.org/10.1177/0309132510362603.

Ferguson, James 2005. Seeing Like an Oil Company: Space, Security, and Global Capital in neoliberal Africa. American Anthropologist 107 (3): 377-382. https://doi.org/10.1525/aa.2005.107.3.377.

Galudra, Gamma, and Ujjwal P. Pradhan, Idrs Sardi, B. L. Suyanto and Meine van Noordwijk 2010. Hot Spot Emissions and Confusion: Land Tenure Insecurity, Contested Policies and Competing Claims to Central Kalimantan Ex-Mega Rice Project Area. Working Paper no. 98. World Agroforestry Centre. https://doi.org/10.5716/WP16601.PDF.

Haraway, Donna 1991. Simians, Cyborgs, and Women: The Reinvention of Nature. London: Free Association Books.

Head, Lesley, Jennifer Atchison, Catherine Phillips and Kathleen Buckinham 2014. Vegetal politics: belonging, practices and places. Social and Cultural Geography 15 (8): 861-870.

https://doi.org/10.1080/14649365.2014.973900.

Ingold, Tim 2011. Being Alive: Essays on Movement, Knowledge and Description. London: Routledge.

https://doi.org/10.4324/9780203818336.

Lensa Kalteng 2016. Program HTR dalam tahap realisasi. Lensa Kalteng, 9 November.

https://lensakalteng.com/2016/11/program-htr-dalamtahap-realisasi\%. <Accessed 9 June 2021>

Kelly, Alice and Nancy Peluso 2015. Frontiers of Commodification: State Lands and Their Formalization. Society \& Natural Resources 28 (5): 473-495.

https://doi.org/10.1080/08941920.2015.1014602.

Kirksey Eben and Stefan Helmreich 2010. The Emerging Multispecies Ethnography. Cultural Antbropology 25 (4): 545-576.

https://doi.org/10.1111/j.1548-1360.2010.01069.x.

Kohn, Eduardo 2014. How Forests Think: Toward an Anthropology Beyond the Human. Berkeley: University of California Press.

https://doi.org/10.1525/9780520956865.

Kop, Jan, Eim Ravensteijn and Kasper Kop (eds) 2015. Irrigation Revisited: An Anthology of Indonesian-Dutch Cooperation 1965-2015. Delft: Eburon Academic Publications.
Krause, Franz 2017. Towards an Amphibious Anthropology of Delta Life. Human Ecology 45 (3): 403-408.

https://doi.org/10.1007/s10745-017-9902-9.

Li, Tania M. 2005. Beyond 'the State' and Failed Schemes. American Anthropologist 107 (3): 383-394. https://doi.org/10.1525/aa.2005.107.3.383.

Li, Tania M. 2008. Contested Commodifications: Struggles over Nature in a National Park. In Joseph Nevins and Nancy Peluso (eds). Taking Southeast Asia to Market: Commodities, Nature, and People in the Neoliberal Age. Ithaca: Cornell University Press. http://hdl.handle.net/1807/67832.

McCarthy, John 2013. Tenure and Transformation in Central Kalimantan: After the "Million hectare" project. In Anton Lucas and Carol Warren (eds). Land for the People: The State and Agrarian Conflict in Indonesia. Ohio: Ohio University Press.

Ministry of Environment and Forestry. 2018. The State of Indonesia's Forests. Ministry of Environment and Foresty, Republic of Indonesia.

Mulyani, Mari and Paul Jepson 2015. Social Learning Through a REDD+ 'Village Agreement': Insights from the KFCP in Indonesia. Asia Pacific Viewpoint 56 (1): 79-95.

https://doi.org/10.1111/apv.12083.

Nygren, Anja 2005. Community-Based Forest Management Within the Context of Institutional Decentralization in Hoduras. World Development 33 (4): 639-655.

https://doi.org/10.1016/j.worlddev.2004.11.002.

Peluso, Nancy 2012. What's Nature Got to Do with It? A Situated Historical Perspective on SocioNatural Commodities. Development and Change 43 (1): 79-104.

https://doi.org/10.1111/j.1467-7660.2012.01755.x.

Peluso, Nancy and Peter Vandergeest 2020. Writing Political Forests. Antipode 52 (4): 1083-1103. https://doi.org/10.1111/anti.12636.

The Ministry of Environment and Forestry (Kementerian Lingkungan Hidup dan Kebutanan) (n.d.) http://pkps.menlhk.go.id/. <Accessed 8 November 2021> 
Prahara, Ari 2019. Kepala Badan Restorasi Gambut Lakukan Kunjungan Kerja ke Provinsi Kalimantan Tengah.

https://mmc.kalteng.go.id/berita/read/7835/kepalabadan-restorasi-gambut-lakukan-kunjungan-kerjake-provinsi-kalimantan-tengah

$<$ Accessed 9 June 2021>

Profil Desa dan Kelurahan 2017. Government publication: Pulang Pisau, Central Kalimantan.

Resosudarmo, Ida Aju Pradnja, Luca Tacconi, Sean Sloan, Faridh Almuhayat Uhib Hamdani, Subarudi, Iis Alviya, and Muhammad Zahrul Muttaqin 2019. Indonesia's Land Reform: Implications for Local Livelihoods and Climate Change. Forest Policy and Economics 108: 1-14. https://doi.org/10.1016/j.forpol.2019.04.007.

Ringkasan eksekutif. Kajian Lingkungan Hidup Strategis (KHLS) RTRW, Kabupaten Pulang Pisau tahun 2014-2034. 2014. Government publication: Pulang Pisau, Central Kalimantan.

Rondonuwu, Olivia, David Fogarty and Niluksi Koswonage 2012. Insight: Environment or ProfitPalm Oil Firm Tests Indonesia. Reuters, 12 July. https://www.reuters.com/article/us-indonesiaforests/insight-environment-or-profit-palm-oilfirm-tests-indonesia-idUSBRE86B0AO20120712. $<$ Accessed 8 November 2021>

Sahala, Roni 2016. Menteri LHK tinjau lokasi pabrik pengolahan sengon di Pulang Pisau. BorneOnews: Suara Rakyat Kalimantan, 15 December. https://tes.borneonews.co.id/berita/45328-menterilhk-tinjau-lokasi-pabrik-pengolahan-sengon-dipulang-pisau <Accessed 9 June 2021>

Sheridan, Michael 2016. Boundary Plants, the Social Production of Space, and Vegetative Agency in Agrarian Societies. Environment and Society (7) 1: 29-49.

https://doi.org/10.3167/ares.2016.070103.

Scott, James C. 1998. Seeing Like a State: How Certain Schemes to Improve the Human Condition Have Failed. New Haven: Yale University Press.

Scott, James 2009. The Art of Not Being Governed: An Anarchist History of Upland Southeast Asia. New Haven: Yale University Press.
Schophuys, H.J. 1953. Regional Development Corporation: Polderplan Kalimantan. Government Publication, Pimpinan Polderplan Kalimantan.

Schreer, Viola 2016. Learning Knowledge About Rattan (Calamoideae arecaceae) and its Uses Amongst Ngaju Dayak in Indonesian Borneo. Journal of Ethnobiology 36 (1): 125-146.

https://doi.org/10.2993/0278-0771-36.1.125.

Tempo 1979. Sebuah Polder telah sia-sia; sebuab irigasi polder yang dibangun untuk mengairi sawah penduduk E transmigran Java di hilir sungai Kahayan, Kal-teng sudab tidak berfungsi lagi. Tempo, 28.

Tsing, Anna Lowenhaupt 2005. Friction: An Ethnography of Global Connection. Princeton: Princeton University Press.

https://doi.org/10.1515/9781400830596.

Tsing, Anna Lowenhaupt 2015. The Mushroom at the End of the World: On the Possibility of Life in Capitalist Ruins. Princeton: Princeton University Press. https://doi.org/10.1515/9781400873548.

Wadley, Reed 2003. Lines in the Forest: Internal Territorialization and Local Accommodation in West Kalimantan, Indonesia (1865-1979). South East Asia Research 11 (1): 91-112.

https://doi.org/10.5367/000000003101297151.

Vandergeest, Peter and Nancy Peluso 1995. Territorialization and State Power in Thailand. Theory and Society 24 (3): 385-426.

https://doi.org/10.1007/BF00993352.

Verdery, Katherine 2002. Seeing Like a Mayor: Or How Local Officials Obstructed Romanian Land Restitution. Ethnography 3 (1): 5-33.

https://doi.org/10.1177/14661380222231054.

ANU LOUNELA

UNIVERSITY RESEARCHER

SOCIAL AND CULTURAL

ANTHROPOLOGY

UNIVERSITY OF HELSINKI

anu.lounela@helsinki.fi 